International Journal of Instruction e-ISSN: 1308-1470 • www.e-iji.net

Received: 29/05/2019

Revision: 22/03/2020

Accepted: 10/04/2020

OnlineFirst:05/07/2020

\title{
Academic Self-Handicapping Scale: Development and Validation in Indian Context
}

\section{Savita Gupta}

Prof., Faculty of Education, Lovely Professional University, Phagwara, India, savita.gupta@lpu.co.in

\section{Ms. Geetika}

Research Scholar, Department of Education, Lovely Professional University, Phagwara, India, geet14geetika@gmail.com

Self-handicapping is a commonly utilized strategy to manage the menace to selfesteem, which gets evoked by failing fear in academic achievement. The main aim of current study was to develop and validate academic self-handicapping scale. This scale was developed for measuring self-handicapping among secondary school students. The study sample comprised three hundred thirty secondary school students. Sample was chosen via using random sampling technique. Opinions of expert were collected to check the scale content and face validity. Factor analysis was done on responses of the sample. The findings concluded that academic self-handicapping can be disintegrated into two factors i.e. behavioural self-handicapping and claimed self-handicapping. Cronbach's alpha of academic self-handicapping $(\alpha=.917)$, the internal consistency indices represented good internal reliability. The results unveiled the existence of significant psychometric features of constructed questionnaire.

Keywords: academic self-handicapping, secondary school students, scale development, factor analysis, academic achievement

\section{INTRODUCTION}

Self-handicapping is defined in diverse ways by numerous research scholars, majority of them concured that self-handicapping includes generating obstructions to auspicious task performance that the learner thinks prominent (Covington, 1992; Tice, 1991; Rhodewalt, 1994). Self-handicapping provides the chance to individual to protect his frail image by internalize triumph and externalize defeat. Mostly, the impediment is considered as external, but sometime as internal to the self-handicapper, not including their potentialities and capabilities. Self-handicapping includes generating inhibitions/ hindrances to performance for enhancing or securing one's perceived potentialities

Citation: Gupta, S., \& Geetika, M. (2020). Academic Self-Handicapping Scale: Development and Validation in Indian Context. International Journal of Instruction, 13(4), 87-102. https://doi.org/10.29333/iji.2020.1346a 
(Berglas \& Jones, 1978). Self-handicapping consists of actions that happen before or concurrently with the task of achievement, not afterwards the task has happened. Illustrations of academic self-handicapping comprise procrastinating, asserting illness or test anxiety and effort withdrawal (Midgley \& Urdan, 2001).

Various researches have been conducted having "self-handicapping" concept in the academic/institutional context. (Chorba \& Isaacson 2012; Beck, Koons \& Milgrim 2000). Self-handicapping can appear practically in any condition that includes capability and diagnostic performances. Classrooms and schools yield marvellous real-world conditions for evaluating behaviour of self-handicapping, because in this academic ecosystem, students regularly face different circumstances and tasks which contain information about their intelligence and capability. Performance of students on academic activities has results on pertinent outcomes (e.g. chances of matriculation, higher studies, their grades and job opportunities). The appearance of friends and teachers in these conditions of achievement permits for recurrent chances to control the other's perception, which is self-handicapper's primary goal. In addition, schools provide situations to analyse both one's self-handicapping nature and the feasible environmental impact on self-handicapping behaviour. The academic self-handicapping implies that the pupil applies varied techniques to rationalize his academic non-success, and it implies the unclear connection between attributes/ personality and student's academic performance (Akın, Abacı \& Akın, 2011). As illustration, when few students experience the non-success probability, students show alike behaviours as reducing their endeavour, or postponing study or less time sparing for study. Students ascribe their failures greater to such types of strategies than to their capacities/skills (Cavendish, 2005). Generally, study has revealed that the academic self-handicapping behaviour associated to motivation of student as well as perceived targets of class, performance qualities, managing strategies, spared study time and finally academic achievement (Akın, Abacı \& Akın, 2011; Thomas \& Gadbois, 2007). These types of variables are associated to how the students explain themselves as learners. Findings of the researches on self-handicapping revealed that students showed low academic success by pretending handicap themselves. They use coping strategies which are non-functional. The investigators observed that students using self-handicapping strategies have greater negative personality characteristics (Kimble, McCrea\& Hirt, 2000).

A piercing examination of academic self-handicapping recommends that a valid and reliable scale should be generated and the academic self-handicapping construct should be reanalysed in each context. Academic self-handicapping behaviour provides various educational implications to policy makers and field experts. There is negative effect of Self-handicapping on major academic outcomes and activities like achievement as well as motivation (Zuckerman, Kieffer, \& Knee, 1998; Urdan, Midgley, \& Anderman, 1998; Martin, Marsh, \& Debus, 2001). Previous studies have revealed that self-handicapping behavior as one of the major academic behaviour in both higher and lower level students (Berglas \& Jones 1978; Rhodewalt \& Davidson, 1986; Higgins \& Hariss, 1988; Tice \& Baumeister, 1990; Shepperd \& Arkin, 1989). Self-Handicappers follow the cycle of failure - self-handicapping - failure which consequences effort withdrawal in school, leading to dropping out of the activity (Urdan \& Midgley, 2001; Zuckerman et al. 
1998). Since self-handicapping has adverse effect on both performances as well as on motivation, it is required to understand differences in handicapping among students and the best methodology for examining handicapping (Midgley and Urdan, 2001). In contrast of these findings, Garcia (1995) found that self-handicapping was a strategy used for regulating affective responses towards failure, and Also, Drexler et al., 1995 proved that self-handicappers faced a smaller decrease in positive affect after failure than non-handicappers do. Hence, this is necessary for the researchers to observe the way in which academic self-handicapping effect the human resources development results in educational settings. Thus, the foremost aim of this research is to develop questionnaire that might carry adequate psychometric properties defining consistency and accuracy of evaluation.

\section{CONTEXT \& REVIEW OF LITERATURE}

The Scale of Self-Handicapping was initially constructed to compute self-handicapping behaviour over whole domains, although this had been validated primarily in educational settings. However reliability and validation of self-handicapping scale in educational contexts was better, but the scale items was framed more in conventional form and these items were not essentially depict self-handicapping in the educational context (Urdan \& Midgley, 2001). Moreover, a scale was proposed by Murray and Warden (1992), which had more potential to identify persons using strategies of selfhandicapping academically.

Academic Self Handicapping Questionnaire given by Rhodewalt and Jones (1982) (cited in Self-Handicapping Scale, Rhodewalt,1990) adapted by Warden (1987) academic self-handicapping questionnaire (cited in Murray \& Warden, 1992). Academic self-handicapping questionnaire had 22 statements which correlated particularly to institutional conditions. A pilot research had revealed that the academic selfhandicapping questionnaire contained requisite internal consistency $(a=.76$; Murray \& Warden, 1992). The scale had two subscales i.e. behavioural self-handicapping and claimed self-handicapping. The six-item scale was constructed by Midgley and Urdan (1995) to assess behaviour of academic self-handicapping according to the three characteristics essential for the item related to the evaluated construct (Urdan, T., \& Midgley, C. (2001). So, the statements were assuming strategy's precede timing, act of procrastinating and making excuses for handicapping behaviour (Urdan \& Midgley, 2001). Implementation of scale required participants to describe themselves by rating on a Likert scale of five-point varied from 'Not at all true' to 'very true'. Obtaining highest score on this scale showed highest self-handicapping behaviour (Gadbois \& Sturgeon, 2011).

Jones \& Rhodewalt (1982) investigated scale of self-handicapping that contained 25 items designed to compute a proclivity of a person to show self-handicapping behaviour. In every item, students questioned to show their agreement level on a Likert scale of 6point varied from disagree very strongly (0) to agree very much (5). The questionnaire revealed sustainable test-retest reliability $(\mathrm{r}=.74$ after one month) and internal consistency $(\alpha=.79)$ (Rhodewalt, 1990). Little and sustainable reliability showed by Cronbach's alpha of Slovenian translation $(\alpha=.65)$. Construct validity and predictive 
ability of the questionnaire was verified by various researches (Rhodewalt, 1990). Akin, Abaci and Akin (2010) adapted Jones and Rodhewalt (1982) self-handicapping questionnaire having 25 statements, self-describe inventory. Every statement was assessed on a rating scale of 6-point (strongly disagree (1) to strongly agree (6)). Turkish version's language validity revealed that coefficient of correlations among English and Turkish statements varied from .69 to .98. Reliability coefficient of threeweek test-retest method was .84 and the reliability coefficient of internal consistency was .90 . The explanatory factor analysis produced a one-factor solution. Confirmatory factor analysis findings concluded a well fitted one-dimensional model (CFI=.99, RMSEA=.037, IFI=.99, NFI=.98, AGFI=.94, GFI=.97, RFI=.97). To measure academic self-handicapping, a modified version of 6 statement questionnaire was constructed by Urdan, Midgley and Anderman (1998). Every six statements of the self-handicapping scale asked student about precede technique they used to apply for rationalizing little achievement. In modified version, the six items were reworded to ensure that students focused on their mathematics class. Each statement was assessed on a scale of 9-point varies from not at all true (0) to very true (8). As the focus of all items was the active associations between students' perceptions of mathematics construction of impediments to academic work, this scale measured behavioral academic self-handicapping. Midgley, Arunkuman and Urdan (1996) developed the scale, and they translated the scale into Turkish. This scale of self-handicapping was also utilized into the academic environment of students.

Also, Smederevac et al. (2003) used the scale of self-handicapping (Jones \& Rhodewalt, 1982). This scale was self-assess inventory of 25 items, which were scaled on Likert scale of six-point. Cronbach-alpha reliability of translation of test was 0.51 . This foisted the need to minimize the scale' items, also some other researchers used such type of strategy (Strube, 1986). Thus moderately refined reliability scored to 0.67 . Three distinct strategies of self-handicapping reported 3 factors that extricated through factorization: factor 1: verbal justifications; factor 2: delay, the lack of effort; factor 3: internal self-handicapping (through psycho-physical state).

Ganda and Boruchovitch (2015) explored scale of self-handicapping behaviour. This Likert scale contained 24 statements specifically related to educational situations. It consisted options of four answers varied from 'It has nothing to do with me (1)' to 'It describes me really well (4)'. Total score ranged from 24 to 96, which implied that students having high score use the self-handicapping strategies more frequently. This scale contained three factors i.e. failure to control attention, problems preparing an activity, problems with time management. Mwitaa et al. (2011) adapted selfhandicapping scale of Rhodewalt (1990). This scale had been reduced to 20 items and was between 1 and 7 i.e. from disagreeing very much to agreeing very much. The reliability was examined during the pilot study with a sample size of 386 , and Alpha reliability of 0.75 was obtained which was within the range of results that were obtained from the previous studies.

Although various academic self-handicapping questionnaires have been constructed, but in Indian environment none of the scale has been developed. Current research will 
bridge the gap as well as develop statements that have direct implications in Indian scenario. By using this scale investigators will know to recognize the engagement level of secondary school students in academic self-handicapping as behaviour of selfhandicapping has adverse consequences on students. According to Hair et al. (2010) this is necessary to re-evaluate the construct's validity although various effective scales are already involved. This research directly investigates the academic self-handicapping behaviour among secondary school students by using extremely valid as well as reliable questionnaire development process of Churchill (1979) and Hinkin (1995).

\section{METHOD}

\section{Item Generation Procedure}

As per our theoretical structure, we constructed items associated to academic selfhandicapping. The scale items were developed to measure the academic selfhandicapping behaviour of secondary school students. Likert (1932) summated assessment procedure was applied to construct this scale. Based on literature review we found 43 statements associated to academic self-handicapping. Current scale was based on Likert format of 5 point; every item assessed on 5 points, (Strongly Agree (5), Agree (4), Neutral (3), Disagree (2) and Strongly Disagree (1)). The above immense review of literature directed us in constructing a scale having vigorous psychometric properties to assess the academic self-handicapping of secondary school students. These statements to be vigorous were more useful when applied in a Likert format (DeVellis, 2016).

\section{Respondents}

The population used for this study was secondary school students of Punjab state (India). Simple random sampling technique was used to select 330 secondary school students of Punjab state. Random sampling had been chosen for few advantages; involving easy to apply, show low sampling error and representation accuracy (Singh, 2008). Initially, out of twenty-two districts of Punjab state, four districts were selected randomly i.e., Ludhiana, Jalandhar, Pathankot and Amritsar. In these districts, twelve schools were selected via using random technique. Number of students was selected conveniently from these schools which were participants of the study. Respondents were encouraged to accomplish the questionnaire with dutiful request. Returned Questionnaires filled by respondents were checked carefully for misplaced, outliers, comprehensiveness, values and respondent detachment (Hair et al. 2010). The size of sample was appropriate for desirable approaches of EFA as well as CFA differently which was suggested by Heir et al. (2010).

\section{Content Validity}

Content validity was measured when initial draft of 43 items was critically reviewed by five experts. The expert view is a general process of statement development (Netemeyer, Bearden, \& Sharma, 2003; DeVellis, 2016). Each item's content was critically scrutinized by the experts to review the relevancy and suitability of these statements for the academic self-handicapping questionnaire. In the second draft only those items which had minimum $75 \%-85 \%$ agreement of experts with respect to item relevancy were retained. 33 remaining items were absolutely acceptable and pertinent to 
assess the academic self-handicapping of secondary school students in Indian context, confirming the academic self-handicapping scale was an adequate valid questionnaire for piloting.

\section{FINDINGS}

\section{Exploratory Factor Analysis}

Exploratory factor analysis (EFA) is the next step in the stage of scale refinement. For the development and validation of psychological constructs, factor analysis procedure is most commonly used technique (Floyd \& Widaman, 1995). The tests of Barlett Sphericity and Kaiser-Meyer-Olkin (KMO) were used to evaluate whether 33-statement questionnaire was suitable for factor analysis. Various iterative cycles used on set of items for factor analysis. Total variance was described after applying each iteration. Numbers of factors were extracted examined and low communalities factors were deleted that did not correlate. The main purpose was to improve the structure of factor with unambiguous loadings. Value of Kaiser-Meyer-Olkin (KMO) was .850 and it was applied to ascertain either the data set and the size of sampling was appropriate as well as acceptable to the chosen investigation or not. Moreover, the Barlett Sphericity test was applied for evaluating either the data obtained from multi-variant normal distribution or not. Barlett Sphericity test was used as well as significant value was obtained (Chi-square $=2688.725, \mathrm{p}<.01$ ). This is requisite that $\mathrm{KMO}$ value should be .60 or above, as well as the Barlett Sphericity test final result is significant statistically (.60 is the least acceptable coefficient, Tabachnick \& Fidell, 1996). Factor analysis could be conducted was decided with the help of above-mentioned results (Kothari and Garg, 2014).

Table 1

KMO and Bartlett's Test of Sphericity

KMO and Bartlett's Test

\begin{tabular}{lll}
\hline \multicolumn{2}{l}{ Kaiser-Meyer-Olkin Measure of Sampling Adequacy. } & .850 \\
\cline { 2 - 3 } Bartlett's Test of Sphericity & Approx. Chi-Square & 3557.057 \\
\cline { 2 - 3 } & Df & 496 \\
\cline { 2 - 3 } & Sig. & .000 \\
\hline
\end{tabular}

Since the loading of factors reveals the association among statements planned to assessed and major structure, pertinent dimensions which occurred in consequence of the analysis of basic component and the factor loading were scrutinized. Thereafter, final structure with 32 statements produced as the academic self-handicapping questionnaire. Varimax method was used to convert rotated component matrix and results acquired from EFA, same is shown in Table No. 2. Varimax method is vertical rotating method, was selected so to make sure that the variances of factor with a few variables would have high value. Four factor structure revealed by factor analysis which explaining variance of $53.67 \%$ (Streiner, 1994) and items loading of all the statements is above .40 (Hair et al., 2010 cited that Item loading acceptable is 0.40). Behavioural Self-Handicapping associated first factor (seventeen items), Claimed self-handicapping associated to second factor (seven items), Problems preparing an activity associated third factor (four items), and Failure to control attention associated to fourth factor (five 
items). The Table 2 indicates statements of academic self-handicapping questionnaire and factor loading of each statement.

Table 2

Statements Related to Academic Self-Handicapping Scale and Factor Loadings of Each Statement

\begin{tabular}{|c|c|c|}
\hline \multirow{2}{*}{\multicolumn{3}{|c|}{$\begin{array}{lr}\text { Items } & \text { Statements } \\
\text { Dimension 1: Behavioural Self-Handicapping }\end{array}$}} \\
\hline & & \\
\hline Item 1 & I delay the school project assigned until the last minute. & .654 \\
\hline Item 2 & I do not do my homework intentionally. & .671 \\
\hline Item 3 & $\begin{array}{l}\text { Instead of spending time on study, I spend lot of time } \\
\text { on unimportant activities. }\end{array}$ & .638 \\
\hline Item 4 & I usually get distracted while studying. & .490 \\
\hline Item 6 & $\begin{array}{l}\text { I tend to avoid competitions, If I have fear } \\
\text { of its poor performance. }\end{array}$ & .602 \\
\hline Item 7 & I always try to put my best in exams. & .640 \\
\hline Item 8 & I tend to study an important exam just a night before. & .685 \\
\hline Item 9 & My goal in life is to be perfect in all aspects. & .655 \\
\hline Item 11 & My concentration span for class work is very short. & .624 \\
\hline Item 12 & I always try to do my best in studies, whatever may be the circumstances & 619 \\
\hline Item 13 & I spend lot of time on social networking sites. & .618 \\
\hline Item 14 & I turn up the music while studying. & .471 \\
\hline Item 15 & I spend lot of time in watching TV serials. & .591 \\
\hline Item 18 & I do not do well in study due to my teacher's attitude towards me. & .555 \\
\hline Item 19 & I overeat more often during exams. & .498 \\
\hline Item 20 & I do my homework on time & .504 \\
\hline Item 21 & I would do better in studies if I work hard. & .506 \\
\hline \multicolumn{3}{|c|}{ Dimension 2: Claimed Self-Handicapping } \\
\hline Item 5 & I fail in exams due to unforeseen circumstances & .401 \\
\hline Item 16 & I get very worried before exams & .735 \\
\hline Item 17 & $\begin{array}{l}\text { I am unable to prepare fully for exams because of } \\
\text { anxiety and nervousness. }\end{array}$ & .632 \\
\hline Item 22 & $\begin{array}{l}\text { My precious study time gets wasted as my parents force } \\
\text { me into household work. }\end{array}$ & .801 \\
\hline Item 23 & Most of the time, I get ill before an exam. & .562 \\
\hline Item 24 & Obstacles come in my way, Whenever I try to study & .787 \\
\hline \multicolumn{3}{|c|}{ Dimension 3: Problems preparing an activity } \\
\hline Item 30 & $\begin{array}{l}\text { I maintain enough energy level to carry on my everyday } \\
\text { work smoothly. }\end{array}$ & .518 \\
\hline Item 31 & I get mentally exhausted during exams & .726 \\
\hline Item 32 & My school work gets affected because of fatigue. & .808 \\
\hline Item 33 & I like appreciation for good work. & .753 \\
\hline \multicolumn{3}{|c|}{ Dimension 4: Failure to control attention } \\
\hline Item 25 & $\begin{array}{l}\text { I cannot complete school assignment because of overburden } \\
\text { of school work. }\end{array}$ & .513 \\
\hline Item 26 & I do not let any type of interference in my school work. & .609 \\
\hline Item 27 & Many times, what I learn for exams do not help me & .703 \\
\hline Item 28 & While studying, I often suffer from headache. & .584 \\
\hline Item 29 & Soon I get tired when I study. & .662 \\
\hline
\end{tabular}




\section{Confirmatory Factor Analysis}

Sorbom \& Joreskog (2004) given confirmatory factor analysis as a Structural Equation Modelling distinct instance that is known as the "linear structural relationship model." To give evidence of validity, CFA is a convenient procedure of statistics (Gerbing, \& Hunter 1982), that is useful after evaluation of constructs along various statements, when there exist linear relationship between the questionnaire items and the questionnaire average or total, as well as during the time a researcher has initial information about which constructs assess which item. It is a statistical procedure applied to a set of observed variables to confirm the factor structure. Confirmatory Factor Analysis enable the examiner to evaluate the hypothesis and the hypothesis states that there exists relationship between the quiescent constructs and underlying existed observe variables (Suhr, 2006).

CFA was processed on four factors obtained from EFA by using SPSS Amos 22 version. The model's indices were Comparative Fit Index $(\mathrm{CFI})=0.909, \mathrm{CMIN} / \mathrm{DF}=2.345$, Chisquare $=687.057(\mathrm{p}>0.01)$, Adjusted Goodness Fit Index (AGFI) $=0.883$, Root Mean Square of Approximation $($ RMSEA) $=0.064$ and Goodness Fit Index $(\mathrm{GFI})=0.912$. The above good model fit indices were achieved only after correlating the error terms (e14 and e15, e6 and e8, e17 and e23). Further, some items have shown very low factor loadings and were deleted as item 19 on first dimension. In addition, after deleting two items from the third dimensions and three items from fourth dimension due to their very low factor loadings, only two items for each of these two dimensions were retained. According to Hair et al. (2010) dimensions with below the three items in number need not to be carried forward, therefore, these two dimensions having only two items each were deleted from further process. The model has been considered having 22 items divided into two dimensions i.e. Behavioural self-handicapping and Claimed selfhandicapping of the construct. 


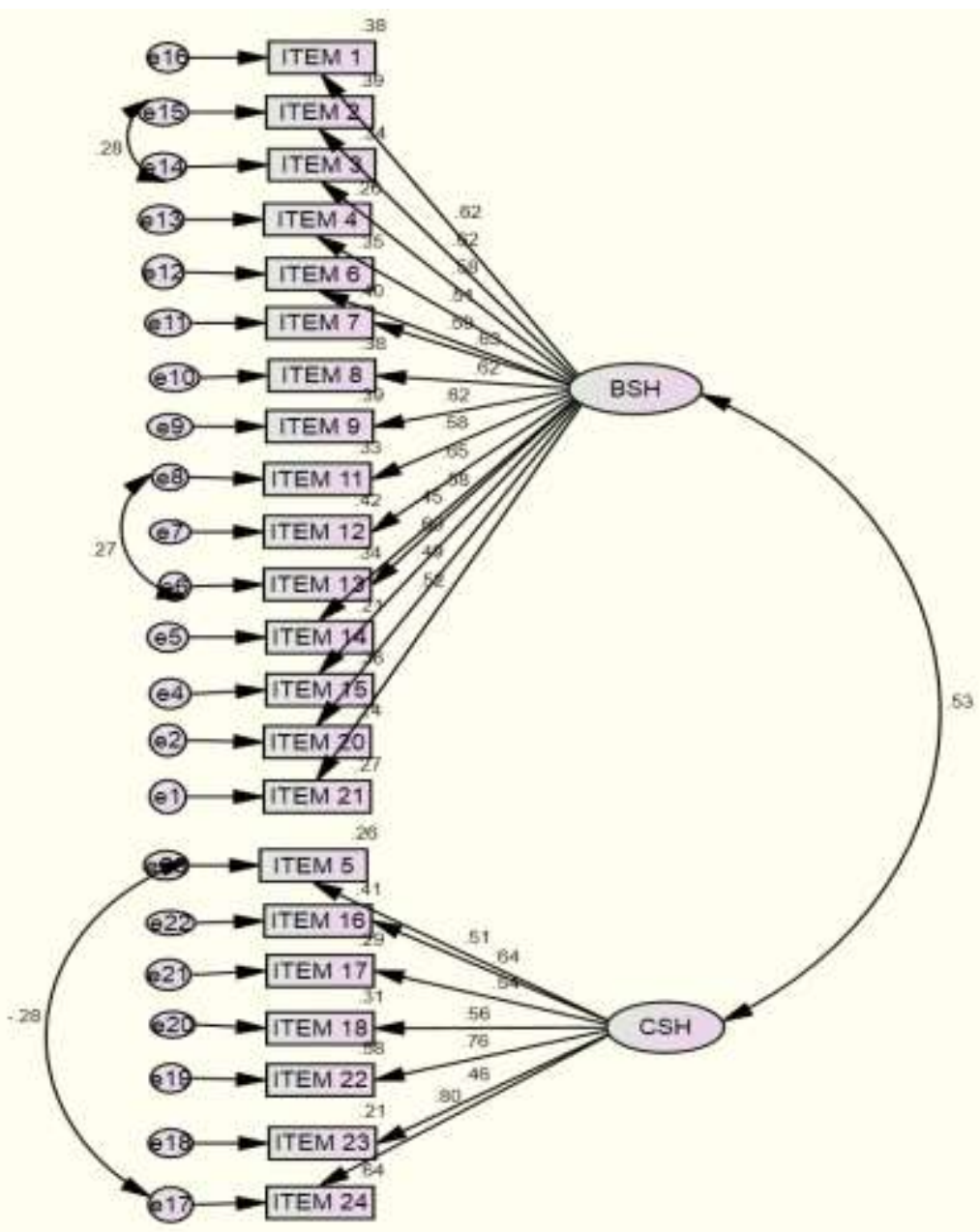

Figure1

Confirmatory Factor Analysis

\section{Reliability Analysis}

The internal consistency of each factor is greater than the recommended coefficient of 0.6 (Hair, et al. 2010). Also, various researches Javanmard et al. (2011); Rhodewalt (1990); Mwitaa et al. (2015); Murray \& Warden (1992) found value of Cronbach's Alpha which is lower than .80. Some studies Urdan \& Midgley (2001); Urdan, Midgley and Anderman (1998), have value of Cronbach's Alpha ranges from 0.80 to 0.86 . Further, value of Cronbach's Alpha for overall scale was found to be .918. This shows high degree of internal consistency among all statements. Gliem \& Gilem (2003) reported that the coefficient of reliability Alpha generally lie between 0 and 1 . George \& 
Mallery (2003) defined the thumb rule to explain Cronbach's alpha which state that "Alpha value lie between 0.80 to 0.9 is Good; and above 0.9 is Excellent". Thus, Cronbach's alpha of academic self-handicapping $(\alpha=.918)$ for the current scale, shows good internal reliability. Similarly, Akın, Abacı, and Akın (2010) showed Cronbach's Alpha value .90 in SHS scale of one factor. Hence, our analysis of reliability recommends that academic self-handicapping scale is consistent internally. Reliability measurement is present in table 3 .

Table 3

Academic Self-Handicapping Scale Reliability Statistics

\begin{tabular}{llcr}
$\begin{array}{l}\text { Sr. No. } \\
\text { Items }\end{array}$ & Construct & Cronbach's Alpha & Number of \\
\hline 1. & Behavioural Self-Handicapping & .893 & 15 \\
\hline 2. & Claimed Self-Handicapping & .742 & 7 \\
\hline 3 & Academic Self-Handicapping Scale & .918 & 22 \\
\hline
\end{tabular}

\section{Construct Validity of Academic Self-Handicapping Scale}

To establish construct validity includes experimental assessment of validity and reliability (discriminant and convergent). Average Variance Extracted (AVE) and Composite reliability (CR) measures are applied to assess convergent validity. Internal consistency measurement of the scale's construct is the Composite Reliability, although Average variance extracted is the variable's variance extent that is described by quiescent construct. After constrains are reached for creating convergent validity; Composite reliability should be more than 0.7, Average Variance Extracted should be more than 0.5 , and composite reliability should be more than Average Variance Extracted, in every construct dimension. For both dimensions of the construct $C R$ value is greater than 0.7, AVE value is greater than 0.5 and Composite reliability is more than Average Variance Extracted. So, Convergent validity for this construct is created. Squared inter-construct correlation (SIC) for both these dimensions is less than Average Variance Extracted (AVE), which indicates the discriminant validity of the dimensions. So, construct validity of the measurement scale is created by both convergent and discriminant validity as depicted in table 4 .

Table 4

Validity Measures Calculated by Microsoft Excel-Based Validity Concerns Toolkit

\begin{tabular}{lll}
\hline Dimensions & Composite Reliability & Average Variance Extracted \\
\hline Behavioural Self-Handicapping & 0.938 & 0.533 \\
\hline Claimed Self-Handicapping & 0.8708 & 0.587 \\
\hline
\end{tabular}

\section{DISCUSSION AND CONCLUSION}

The questionnaire established in this study can assess the academic self-handicapping of secondary school students. The foremost aim of this paper is to validate and create a scale which would produce reliable and valid outcomes in academic self-handicapping of the secondary school students. This research obtained on a wide literature review of 
researches assessing academic self-handicapping within a span of educational environment. Current paper has introduced the meticulous methodological process accomplish to quantitatively validate and develop a scale assessing academic selfhandicapping behaviour of Indian secondary school students. In consideration of the expert opinion, the whole group of 43 items was proposed. Expert were requested to give the suggestion for statement of the scale on the bases of some particular parameter i.e. ambiguity, vagueness, or dual meaning. Moreover, opinions of expert were collected for the purpose to assess the face validity and content validity. Initially made 10statements were deleted from the statement pool. Hence, 33 items were consisted in final draft. It is a Likert 5-point scale format. The range of the score was lie between 1 and 5. One for strongly agree and five for strongly disagree. EFA and CFA was use to analyse scale Structural validity. After EFA, thirty-two statements were kept from the scale and four factors structure was obtained. The values of factor loading ranged between .401 to .801 of the items and explained $53.679 \%$ of the total variance.

EFA concluded that academic self-handicapping can be conceptualized or decomposed in four factors containing of behavioural self-handicapping (17 statements), Claimed self-handicapping (07 statements), Problems preparing an activity (04 statements) and Failure to control attention (05 items) commonly. Likewise, to measure the factor structure of the academic self-handicapping scale, confirmatory factor analysis was applied. Following factors which were acquired through EFA were checked with CFA. In CFA, good model fit indices were achieved only after correlating the error terms (e14 and e15, e6 and e8, e17 and e23). Further, some items had shown very low factor loadings and were deleted as item 19 on first dimension. In addition, after deleting two items from the third dimensions and three statements from fourth dimension due to their very low factor loadings, only two items from each of these two dimensions were retained. According to Hair et al. (2010) dimensions with below the number of three items need not to be carried forward; therefore, these two dimensions having only two items each were deleted for further process. The model has been considered having only 22 items divided into two dimensions viz. Behavioural self-handicapping and Claimed self-handicapping of the construct. The model's indices were Comparative Fit Index $(\mathrm{CFI})=0.909, \mathrm{CMIN} / \mathrm{DF}=2.345$, Chi-square=687. $057(\mathrm{p}>0.01)$, Adjusted Goodness Fit Index $($ AGFI $)=0.883$, Root Mean Square of Approximation $($ RMSEA $)=0.064$ and Goodness Fit Index $(\mathrm{GFI})=0.912$. Furthermore, coefficient of reliability was calculated which showed internal consistency with high degree $(\alpha=.918)$ that was better as accepted by George \& Mallery (2003). Current study fulfils whole standards i.e. reliability, construct validity and structural validity.

The scale has ample theoretical buttress and also has adequate statistical support. The broad previous empirical studies support the factors which were retained in the scale after applying EFA and CFA. Previous studies i.e. Warden, 1987, Murray \& Warden, 1992 support the Behavioural self-handicapping factor obtained in this study. Similarly, claimed self-handicapping was used by prior researchers like (Warden, 1987, Murray \& Warden, 1992). However the results of this study is contrary to other studies like Jones and Rhodewalt (1982), Rhodewalt (1990), Akın, Abacı and Akın (2010) which take academic self-handicapping scale as single factor model, Urdan and Midgley, 2001 
which uses three factor (precede timing, act of procrastinating and making excuses ) of self-handicapping questionnaire.

Causes of academic self-handicapping are feeling of self-conscious (Midgley and Urdan, 1995; Shepperd and Arkin, 1989), protect oneself from perceptions of others (Kolditz and Arkin, 1982), low feelings of self-determination (Zuckerman, Kieffer and Knee 1998), a belief in innate ability (Rhodewalt, 1994), low self-esteem (Leondari and Gonida, 2007) and procrastination (Ferrari and Tice, 2000).

Lastly, the evidence which was provided from previous studies proposes that current questionnaire has strong psychometric properties to assess academic self-handicapping of secondary school students. At last, this was inferred that the scale obtained reliable and valid outcomes, and can be applied to assess academic self-handicapping of secondary school students.

As the academic self-handicapping strategy thwarts achievement and cause withdrawal from activities of academic achievement for long-term (Zuckerman, Kieffer, \& Knee, 1998; Urdan, Midgley, \& Anderman, 1998; Martin, Marsh, \& Debus, 2001), it makes pivotal for parents and teachers to dissuade behaviour which encourage selfhandicapping and keep away from behaviour which promote it. This indicates that there is a sufficient requirement to create educational intercessions that pivot clearly on decreasing self-handicapping behaviour within students. Students can be motivated to give greater attention towards their learning and occupied in a discourse which manage the phase for fruitful growth and adaptations

\section{Limitations}

In current study, investigator has applied extremely reliable and valid scale development processes, still this have few drawbacks. The foremost drawback is that exploratory and confirmatory factor analysis procedures used for the scale rectification are completely based on specific sample-size. Current research has a complete literature support and rationale for using these procedures, however to achieve best outcomes a large size of sample is recommended. The research assesses two dimensions of academic selfhandicapping, and this scale based on Likert 5-point varies from strongly agrees to strongly disagree. More investigation is required to measure the concurrent as well as discriminant validity. The major problem of this current scale development is the complication related with producing scores which are reliable and valid. These results give support for organizing advanced investigation of psychometric properties on the academic self-handicapping questionnaire.

\section{Suggestions for Further Research}

Due to prevalent academic self-handicapping behaviour in India, further research must seek to ascertain appropriateness of this scale for applying it on other population of selfhandicappers. In academic institutions, to measure the consequences as well as causes of academic self-handicapping an approach of triangulation can be applied. Also, multiinstitutions research should be organized to measure the attitude of students and teachers 
about academic self-handicapping. Further study can be organized to ascertain the association of academic self-handicapping with the academic achievement of students.

\section{REFERENCES}

Akın, A., Abacı, R. \& Akın, U. (2011). Self-handicapping: A conceptual analysis. International Online Journal of Educational Sciences, 3(3), 1155-1168

Akin, A. (2011). Academic locus of control and self-handicapping. Procedia-Social and Behavioral Sciences, 30, 812-816.

Akın, A., Abac1, R., \& Akın, Ü. (2010). Self-handicapping Scale: A study of validity and reliability. Paper presented at the 16th National Psychology Congress, 14-17 April. Mersin, Turkey.

Akın, A. (2012). Academic locus of control and self-handicapping. Procedia-Social and Behavioral Sciences, 30, 812-816.

Bashir, H., \& Bala, R. (2018). Development and validation of academic dishonesty scale (ADS): Presenting a multidimensional scale. Int. J. of Instruction, 11(2), 57-74.

Berglas, S. \& Jones, E. E. (1978). Drug choice as a self-handicapping strategy in response to non-contingent success. J. of Personality and Social Psyc., 36, 405-417.

Beck, B. L., Koons, S. R., \& Milgram, D. L. (2000). Correlates and consequences of behavioral procrastination: The effects of academic procrastination, self-consciousness, self-esteem and self-handicapping. Procrastination: Current Issues and New Directions: Journal of Social Behavior and Personality, 15(5), 3-13.

Brown, C. M., \& Kimble, C. E. (2009). Personal, interpersonal, and situational influences on behavioral self-handicapping. The J. of Social Psyc., 149(6), 609-626.

Cavendish, S. (2005). Self-efficacy and use of self-regulated learning strategies and academic self-handicapping among students with learning disabilities (Unpublished doctoral dissertation). Wayne State University.

Chorba, K., Was, C. A., \& Isaacson, R. M. (2012). Individual differences in academic identity and self-handicapping in undergraduate college students. Individual Differences Research, 10(2), 60-68.

Churchill, G.A. Jr. (1979). A paradigm for developing better measures of marketing constructs. Journal of Marketing Research, 16, 64-73.

Covington, M.V. (1992). Making the grade: A self-worth perspective on motivation and school reform. New York: Cambridge University Press.

Dar, I. A. \& Mishra, M. (2018). Internationalisation of SMEs: Development and validation of multi-dimensional measurement scale. International Journal of Entrepreneurship and Small Business, (In production).

DeVellis, R. F. (2016). Scale development: Theory and application. Thousand Oaks, $C A$ : Sage Publications. 
Drexler, L. P., Ahrens, A. H., \& Haaga, D. A. (1995). The affective consequences of selfhandicapping. J. Behavioural Person, 10, 861-870.

Ferrari, J. R., \& Tice, D. M. (2000). Procrastination as a self-handicap for men and women: A task-avoidance strategy in a laboratory setting. Journal of Research in Personality, 34(1), 73-83.

Floyd, F. J., \& Widaman, K. F. (1995). Factor analysis in the development and refinement of clinical assessment instruments. Psychological Asses., 7(3), 286-299.

Gadbois, S. A., \& Sturgeon, R. D. (2011). Academic self-handicapping: Relationships with learning specific and general self-perceptions and academic performance over time. British Journal of Educational Psychology,

Ganda, D. R., \& Boruchovitch, E. (2015). Self-handicapping strategies for learning of pre-service teachers. Estudos de Psicologia, 32(3), 417-425.

George, D., \& Mallery, P. (2003). Reliability analysis. SPSS for Windows, step by step: a simple guide and reference. Boston: Allyn \& Bacon.

Gliem, J. A., \& Gilem, R. R. (2003). Calculating, interpreting, and reporting cronbach's alpha reliability coefficient for likert-type scales. Paper Presented at the Midwest Research-to-Practice Conference in Adult, Continuing, and Community Education, The Ohio State University, Columbus, $\mathrm{OH}$.

Garcia, T. (1995). The role of motivational strategies in self-regulated learning. New Direct. Teach. Learn, 63, 29-42.

Hair, Jr. J. F., Black, W. C., Babin, B. J., \& Anderson, R. E. (2010). Multivariate data analysis. Upper Saddle River: Pearson Education International.

Higgins, R. L., \& Hariss, R.N. (1988). Strategic 'alcohol' use: Drinking to selfhandicap. Journal of Social and Clinical Psychology, 6, 191-202.

Hinkin, T. R. (1995). A brief tutorial on the development of measures for use in survey questionnaires. Organizational Research Methods, 1, 104-121.

Javanmard1, A., Hoshmandja, M., \& Ahmadzade, L. (2011). Investigating the relationship between self-efficacy, cognitive and metacognitive strategies, and academic self-handicapping with academic achievement in male high school students in the tribes of Fars province. Journal of Life Science and Biomedicine, 3(1), 27-34.

Jones, E. E., \& Rhodewalt, F. (1982). The self-handicapping scale. Princeton U.

Kimble, C. E., McCrea, S. M., \& Hirt, E. R. (2000). Public self-focus and sex differences in behavioral self-handicapping: Does increasing self-threat still make it “just a man's game?". Personality and Social Psychology Bulletin, 26(9), 1131-1141.

Kolditz, T. A., \& Arkin, R. M. (1982). An impression management interpretation of self-handicapping strategy. J. Person. Soc. Psychol, 43, 492-502. 
Kothari, C. R., \& Garg, G. (2014). Research methodology methods and techniques. New Delhi: New Age International (P) Limited Publishers.

Leondari, A., \& Gonida, E. (2007). Predicting academic self-handicapping in different age groups: The role of personal achievement goals and social goals. British Journal of Educational Psychology, 77(3), 595-611.

Likert, R. A. (1932). A technique for the measurement of attitudes. Archives of Psychology, 22(140), 55.

Martin, A., Marsh, H., \& Debus, R. (2001). Self-handicapping and defensive pessimism: Exploring a model of predictors and outcomes from a self-protection perspective. Journal of Educational Psychology, 93(1),87-102.

Mwitaa, H. M., Shahabb S. A., Nordinc, M. S., \& Zubair, A. M. (2015). Validation of measures of academic self-handicapping behavior and student engagement on Muslim university students. IIUM Journal of Educational Studies, 3(2), 131-163

Midgley, C., \& Urdan, T. (2001). Academic self-handicapping: What we know, What more is there to learn. Educational Psychology Review, 13(2).

Midgley, C., Arunkumar, R., \& Urdan, T. (1996). If don't do well tomorrow, there's reason: Predictors of adolescents' use academic self-handicapping strategies. Journal of Educational Psychology, 88(3), 423-34.

Midgley, C., \& Urdan, T. (1995). Predictors of middle school students' use of selfhandicapping strategies. Journal of Early Adolescence, 15, 389-411.

Murray, C. B., \& Warden, M. R. (1992). Implications of self-handicapping strategies for academic achievement: A reconceptualization. J. Soc. Psychol, 132, 23-37.

Mwitaa, H. M., Shahabb, S.A., Nordinc, M. S., \& Zubair, A. M. (2015). Validation of measures of academic self- handicapping behavior and student engagement on Muslim university students. IIUM Journal of Educational Studies, 3(2), 131-163.

Netemeyer, R. G., Bearden, W. O., \& Sharma, S. (2003). Scaling procedures: Issues and applications. Sage Publications.

Rhodewalt, F. (1990). Self-handicappers: Individual differences in the preference for anticipatory, self-protective acts. In R. L. Higgins, C. R. Snyder, \& S. Berglas (Eds.), Self-handicapping: The paradox that isn't (pp. 69-106). New York: Plenum Press.

Rhodewalt, F. (1994). Conceptions of ability, achievement goals, and individual differences in self-handicapping behavior: On the application of implicit theories. $J$. Person, 62, 67-85.

Rhodewalt, F., \& Davison, J. (1986). Self-handicapping and subsequent performance: Role of outcome valance and attribution certainty. Basic and Applied Social Psychology, 7, 307-322. 
Schwinger, M., Lemmer, G., Wirthwein, L., \& Steinmayr, R. (2014). Academic selfhandicapping and achievement: A meta-analysis. J of Edu Psychology, 106(3), 744-761.

Shepperd, J. A., \& Arkin, R. M. (1989). Determinants of self-handicapping: Task importance and the effects of pre-existing handicaps on self-generated handicaps. Personality and Social Psychology Bulletin, 15, 101-112.

Singh, A. K. (2008). Tests, measurements and research methods in behavioural sciences. Patna: Bharti Bhawan publishers and distributors.

Smederevac, S., Novović, Z., Milin, P., Janičić, B., Pajić, D., \& Biro, M. (2003). Tendency to self-handicapping in the situation of expected failure. PSIHOLOGIJA, 36 (1-2), 39-58.

Sorbom, D., \& Jöreskog, K. G. (2004). LISREL 8 reference guide. Lincolnwood, IL: Scientific Software International.

Streiner, D. L. (1994). Figuring out factors: The use and misuse of factor analysis. Canadian Journal of Psychiatry, 39, 135-140.

Strube, M.J. (1986). An analysis of self-handicapping scale. Basic and Applied social psychology, 7, 221-224.

Suhr, D. D. (2006). Exploratory or confirmatory factor analysis? (pp. 1-17). Cary: SAS Institute.

Tabachnick, B. G., \& Fidell, L. S. (1996). Using multivariate statistics. New York, NY: Harper Collins College.

Thomas, C. R., \& Gadbois, S. A. (2007). Academic self-handicapping: The role of selfconcept clarity and students' learning strategies. British Journal of Educational Psychology, 77, 101-119.

Tice, D. M., \& Baumeister, R. F. (1990). Self-esteem, self-handicapping, and selfpresentation: The strategy of inadequate practice. Journal of Personality, 58, 443-464.

Tice, D. M. (1991). Esteem protection or enhancement? Self-handicapping motives and attributions differ by trait self-esteem. J. Person. Soc. Psychol, 60, 711-725.

Urdan, T., \& Midgley, C. M. (2001). Academic self-handicapping and achievement goals: A further examination. Contemporary Educational Psychology, 26, 61-75.

Urdan, T., Midgley, C., \& Anderman, E. M. (1998). The role of classroom goal structure in students' use of self-handicapping strategies. American Educational Research Journal, 35, 101, 122.

Uysal, A., \& Lu, Q. (2010). Self-handicapping and pain catastrophizing. Personality and Individual Differences, 49(5), 502-505.

Zuckerman, M., Kieffer, S. C., \& Knee, C. R. (1998). Consequences of selfhandicapping: Effects on coping, academic performance, and adjustment. Journal of Personality and Social Psychology, 74, 1619-1628. 